\title{
Game, Environment and Peer Effect on Children on the Digital Gaming Habits in Game Arcades
}

\author{
Alper ASLAN*1(D), Yiğit Emrah TURGUT 2(D) Türkan KARAKUŞ YILMAZ 3 (D) \\ ${ }^{1}$ Munzur University, Çemişgezek Vocational School, Department of Computer Technology, Tunceli, Turkey alperaslan@gmail.com, \\ ${ }^{2}$ Recep Tayyip Erdoğan University, Faculty of Education, Rize, Turkey, yigitemrah.turgut@erdogan.edu.tr, \\ ${ }^{3}$ Atatürk University, Kazım Karabekir Faculty of Education Erzurum, Turkey, t.karakus@atauni.edu.tr, \\ * Corresponding Author: alperaslan@gmail.com
}

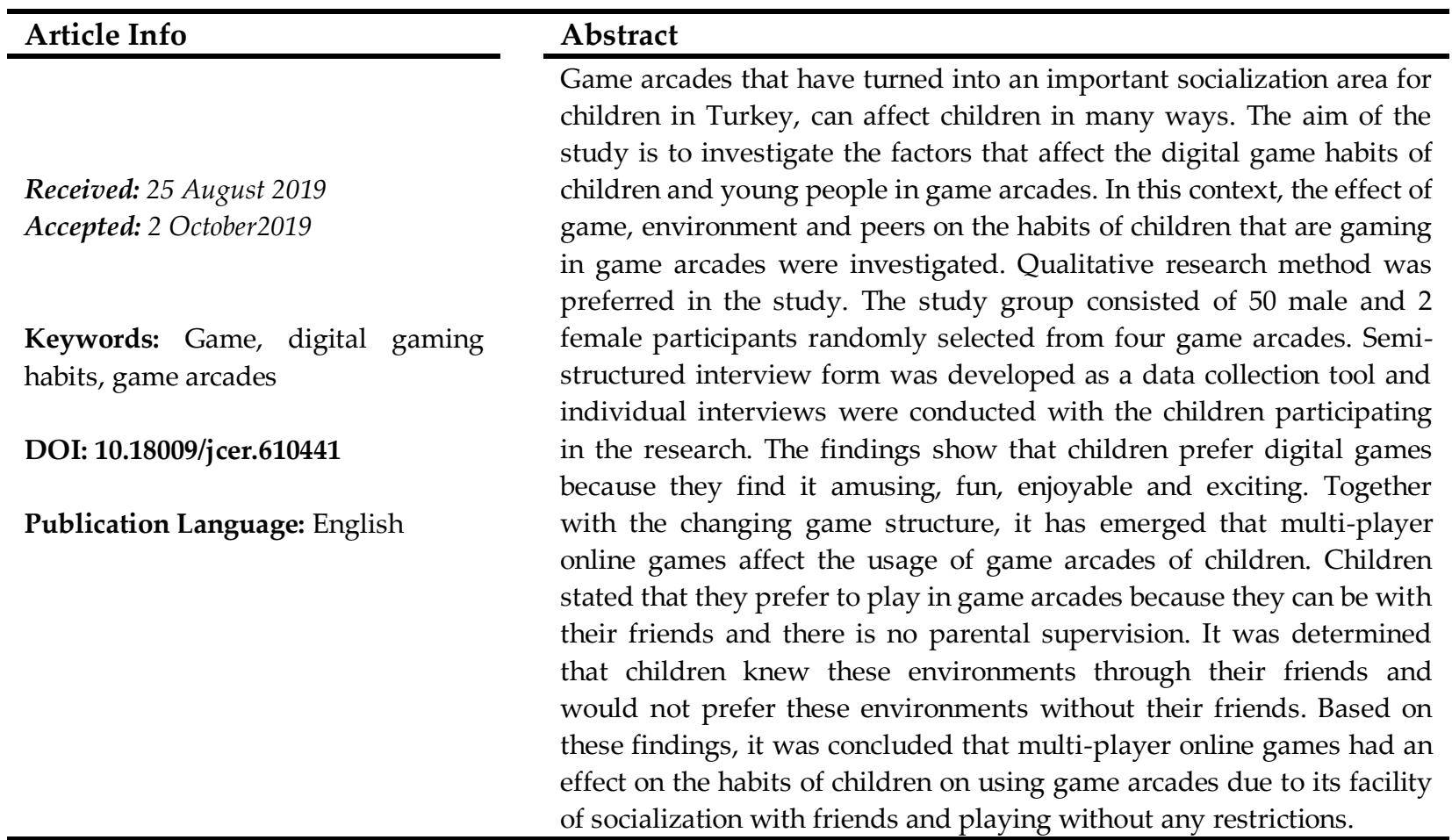

To cite this article: Aslan, A., Turgut, Y.E., \& Karakuş-Yılmaz, T. (2019). Implementation of design-based research in software engineering education: A case of final project course. Journal of Computer and Education Research, 7 (14), 480-495. DOI: 10.18009/jcer.610441

\section{Introduction}

A game is defined as "any kind of competition based on agility, with the aim of developing physical and mental abilities" or "entertainment for having a good time while having certain rules and developing talent and intelligence" (URL-1, 2019). In all age groups, game is a very important social interaction tool (Sherry, Desouza, Greenberg \& Lachlan, 2003). Developing technology has significantly changed the concepts of game and toys (Pala \& Erdem, 2011), the relationship of children with the game and the expectations of parents and educators from the game. With the proliferation of video games in 1990s that first 
emerged in the 1970s, it was seen that children's attitudes, beliefs and behaviors were more influenced by them than traditional media. (Siyez \& Baran, 2017). By the 2000s, the elements of violence in digital games and the time children devoted to play began to increase (Anderson, Gentile \& Buckley, 2007). With the widespread preference of digital games, many stakeholders, from parents to social scientists, educators and politicians, have increased concerns about the impact of digital games on children (Saleem, Anderson \& Gentile, 2012). The increase in the researches about digital games in the literature can be considered as a reflection of this situation (Çavuş, Ayhan \& Tuncer, 2016; Kim \& Smith, 2017; Lin \& Hou, 2016; Thorne, Smith, Morgan, Babic \& Lubans, 2014; Toran, Ulusoy, Aydın, Deveci \& Akbulut, 2016).

There are many factors that affect children's gaming habits. The structure of the constantly developing digital games, preferred places to play and the social environment can be mentioned among these elements. Multi-player online games, in particular, significantly affect children's gaming habits (Kuss \& Griffiths, 2012). Indeed, research shows that multiplayer online games are often preferred by a certain group of gamers (Rehbein, Psych, Kleimann, Mediasci \& Mößle, 2010). While women see digital games as a means of spending more time, men prefer digital games with the desire to make more friends (Ko, et al., 2005). Changes in the places where games and children play also change the tools that children use to socialize (Bat1, 2011). For today's children who consider games as a socialization tool (Binark \& Bayraktutan-Sütçü, 2008), the places where games are played are as important as the games. Of course, at this point, in order to understand better the impact of the place, the advantages of the places that children prefer to play should be evaluated. The places that children prefer to play are sometimes related to the technical infrastructure they have and sometimes with whom the game is played (Pala \& Erdem, 2011). In this context, both the structure of digital games, preferred places to play and the desire of the gamers to be with their peers affect the children's gaming habits.

As a natural consequence of the emergence of the Internet and the fact that it began to find a place in almost every field (Olafsson, Livingstone \& Haddon, 2013), the need for people to access the Internet has gradually increased. Especially after the second half of the 1990s, Internet cafes began to emerge as places where internet access was provided (Yildiz, 2002). In fact, Reinhardt (2001) evaluated these environments as McDonalds of Internet 
access in the face of this development of Internet cafes. Underneath this very rapid widespread adoption and acceptance of Internet cafes in Turkey, we could think that coffeehouse culture in Turkey had a positive influence (Çağlayan, 2001). The concept of "Internet equals entertainment" (Akbulut, 2013), have turned internet cafes into game arcades. Nowadays, the majority of internet cafes are used for gaming and entertainment (Hopcan \& Y1lmaz, 2013). In addition, the places where children can play games that various game consoles are present, serve the same purpose. In this context, the concept of game arcades refers to both internet cafes and other places that provide the opportunity to play digital games.

When the literature is examined, it is seen that games have an important place in the daily lives of children. Moreover, games have become a means of communicating and socializing with friends as well as a means of entertainment for children. With the spread of multi-player games, game arcades have become an environment where the children can be together with their friends, beyond the scope of a place where children can only access games. In this context, it is important to examine the factors that affect the digital playing habits of children in game arcades, to know the reasons for choosing these environments and to predict the problems that may occur. In addition, it is thought that the results of the research can guide the decisions to be taken regarding the usage of game arcades of children.

In this study, the effect of the game, environment and peer on the habits of children on using game arcades were discussed. It is important to examine in depth the factors that affect children's choice of digital games and game arcades, which play an important role in their daily habits, and to explain their social impact and behavior (Tarcan, 2005). As a matter of fact, game arcades are seen as an important socialization area for children (Binark \& Bayraktutan-Sütçü, 2008). In addition, it is possible to come across researches that game arcades increase some risks such as game addiction (Wu \& Cheng, 2007). In this context, it is thought that the factors that affect children's habits on using game arcades will contribute to the literature in order to understand the various opportunities and risks that these environments provide to children. 


\section{The Aim of the Research}

The aim of the study is to investigate the factors that affect the digital gaming habits of children in game arcade. In this context, the effect of the game, environment and peers on children's gaming habits in game arcade were investigated. For this purpose, the answers of the following research questions were sought;

1. What is the effect of the game on children's habits of playing in game arcade?

2. What is the effect of environment on children's habits of playing in game arcade?

What is the effect of peers on children's habits of playing in game arcade?

\section{Method}

In this research, the phenomenology pattern was chosen as one of the qualitative research methods because it was aimed to reveal the game, environment and peer effect on the children's gaming habits, perceptions about game arcades and their lives in these environments. Phenomenology aims to reveal individuals' experiences, perceptions and the meanings attributed to them. (Yıldırım \& Şimşek, 2013). In phenomenology research, the data sources are individuals or groups who experience and focus on the phenomenon that the research focuses on (Yıldırım \& Şimşek, 2013). In this context, 50 males and 2 females between the ages of 9-17 playing games in a randomly selected game arcades in Erzurum were included in the study.

\section{Data Collection Tool}

Individual interviews were preferred in order to reflect the lives of the participants in game arcades. Individual interviews are one of the effective methods used to reveal situations that cannot be observed directly in individuals. Because it is very difficult to reveal the feelings and thoughts of individuals in a realistic way through observation (Glesne, 2012). After receiving expert opinion on the questions prepared for the interviews, a semistructured interview form consisting of 7 questions was developed.

\section{Data Collection Process and Data Analysis}

During the data collection process, individual interviews were conducted with 50 male and 2 female participants, who were randomly selected in game arcades and agreed to voluntarily participate in the study. The interviews were started with a question to determine the reasons for the participants to choose game arcades and the questions were 
directed to the participants with different questions in order to answer the research questions in depth according to the course of the interview. In order to prevent data loss during the interviews, permission was obtained from the participants and the interview was recorded with a voice recorder. After the interviews were completed, the audio recordings were analyzed and transcribed by the researchers. Interviews were analyzed using content analysis method. The findings of the analysis were presented within the framework of the research questions. In the analysis and presentation of the data, the participants were coded as $\mathrm{K} 1, \mathrm{~K} 2$ etc.

In qualitative research, to ensure validity and reliability, the strategies of credibility instead of internal validity, transferability instead of external validity, consistency instead of internal reliability and confirmability instead of external reliability were used (Yıldırım \& Şimşek, 2013). In this context, the following operations were carried out:

- After the interview forms were developed, expert opinion was obtained, and a child was interviewed as example to provide credibility. During the data collection process, children from various age groups were selected and utmost care was given to reveal different perceptions and experiences.

- All stages of the research have been elaborated to ensure transferability. The raw data are presented with detailed descriptions and supported by direct quotations.

- In order to ensure consistency, data were tried to be cleared of prejudices by asking questions in the same order and avoiding directive speeches to the participants.

In order to ensure confirmability; The raw data, coding, findings, comments and suggestions made during the analysis phase were recorded and checked.

\section{Findings}

In this part of the research, the findings obtained by analyzing the data are presented based on the research questions. Firstly, the demographic information of the children such as gender, internet access at home, daily game playing times, environments they play, frequency of going to game arcades are given in Table 1. 
Table 1. Demographic information of the participants

\begin{tabular}{|c|c|c|c|c|c|}
\hline Gender & $f$ & $\%$ & Game Playing Times (Daily) & $f$ & $\%$ \\
\hline Male & 50 & 96 & Less than 1 hour & 5 & 10 \\
\hline \multirow[t]{2}{*}{ Female } & 2 & 4 & 1-2 hours & 30 & 58 \\
\hline & & & More than 3 hours & 17 & 32 \\
\hline Internet Access at Home & $f$ & $\%$ & Environments They Play in & $f$ & $\%$ \\
\hline Present & 30 & 58 & Internet Cafe & 8 & 16 \\
\hline \multirow[t]{7}{*}{ Not Present } & 22 & 42 & Game Arcade & 15 & 29 \\
\hline & & & Both & 29 & 55 \\
\hline & & & Frequency of Going to Game Arcades & $f$ & $\%$ \\
\hline & & & $\begin{array}{ll}\text { Everyday } \\
\end{array}$ & 19 & 33 \\
\hline & & & Three times a week & 11 & 23 \\
\hline & & & Once a week & 14 & 28 \\
\hline & & & Once a month & 8 & 16 \\
\hline
\end{tabular}

As seen in the table, the majority of the participants were boys. It was observed that more than half of the participants had access to the Internet at home. It was found that the majority of children played games for 1-2 hours or more per day, and more than half preferred to play games and both in game arcade and internet cafes.

\section{The Effect of Games on Children's Habits on Using Game Arcades}

Within the framework of the main aim of the study, the effect of games on children's preference of game arcades to play games was investigated. Since it is thought that the game preferences of children can affect the habits of going to game arcades, firstly, why children prefer digital games is examined. The results of the content analysis of the findings are given in Table 2.

Table 2. Factors affecting the preferences of digital games

\begin{tabular}{lc}
\hline Factors Affecting the Preferences of Digital Games & $f$ \\
\hline It is fun, exciting and enjoyable & 24 \\
Boredom & 15 \\
Spending time / leisure time activity & 12 \\
Liking to play digital games & 12 \\
Being together with friends & 8 \\
Stress relief & 7 \\
Quality, vibrant, lifelike graphics & 7 \\
Habit & 2 \\
\hline
\end{tabular}

When the table is examined, according to the opinions received from the children, it is revealed that the fun and enjoyable time factor is the leading factor among the reasons for 
choosing digital games compared to other factors. A participant opinion in this direction is as follows:

"I think playing games is fun, I want to play at every opportunity." K3

"I get carried away while playing games. I think it is very exciting." K12

Some of the participants stated that they prefer digital games to relieve boredom or spend time rather than having fun. A participant's opinion on this subject is as follows:

"When I get bored, I love playing games to spend time with my friends." K7

Some of the participants stated that they prefer digital games especially to be with their friends and spend time with them. One of the views is:

"I love playing games with my friends. I don't play that much on my own." K1

In addition, children's love to play digital games, and stress relief, were found to be effective. Evaluating the digital game preferences of children within the framework of game arcades can provide a perspective. At this point, a question was asked to the children in which environments they prefer to play digital games in order to make the impact of the game more concrete when they prefer game arcades. The findings are presented in Table 3.

Tablo 3. The effect of games on children's preference of environment

\begin{tabular}{|c|c|c|c|}
\hline Games played in game arcades & $f$ & $\begin{array}{l}\text { Games played in other environments } \\
\text { (home, school, etc.) }\end{array}$ & $f$ \\
\hline Pro Evolution Soccer (PES) & 25 & Grand Theft Auto (GTA) & 6 \\
\hline $\begin{array}{l}\text { Fédération Internationale de Football } \\
\text { Association (FIFA) }\end{array}$ & 14 & $\begin{array}{l}\text { Fédération Internationale de Football } \\
\text { Association (FIFA) }\end{array}$ & 3 \\
\hline Call of Duty & 14 & Far Cry & 3 \\
\hline Counter Strike & 6 & Point Blank & 3 \\
\hline Need for Speed & 5 & Metin 2 & 2 \\
\hline Grand Theft Auto(GTA) & 3 & Need for Speed & 2 \\
\hline Other games & 2 & Other games & 3 \\
\hline
\end{tabular}

It was observed that the games most preferred by children differ according to the environment. When the table was examined, children preferred game arcades to play football games such as Pro Evolution Soccer (PES), Fédération Internationale de Football Association (FIFA) and war games such as Call of Duty. In other environments outside game arcades, it was seen that they chose single player games such as Grand Theft Auto (GTA). Some of the opinions of the participants are as follows:

"I love playing PES with my friends. When we go to game arcade we play PES or FIFA." K11

"If I'm home, I'll play GTA or something." K14 
When the findings were examined, it was shown that children preferred game arcades especially for playing multi-player games. For games such as Far Cry, Point Blank that the player can play against the computer, children preferred to play them in the environments different than game arcades.

\section{The Effect of Environment on Children's Habits on Using Game Arcades}

Another sub-research question of the research is to examine the effect of environment on children's habits on using game arcades. In this context, the children were asked a question about why they prefer game arcades to play digital games. The results of the analysis are given in Table 4.

Table 4. The effect of environment on children's environment preferences

\begin{tabular}{lc}
\hline The Effect of Environment & $f$ \\
\hline It is tasteful, attractive and enjoyable & 22 \\
Being together with friends & 17 \\
Physical conditions (Lack of computer / internet / game console etc. facilities at home) & 12 \\
Quality, vibrant, lifelike graphics & 7 \\
Boredom & 6 \\
Pleasant and beautiful environment & 6 \\
The friendliness of the game arcade owner & 4 \\
\hline
\end{tabular}

When we look at the table, among the reasons why children play games in game arcades, the first place went to "digital games that are played in these environments are more enjoyable and attractive". In this respect, the opinion of a participant is as follows:

"I think it is more enjoyable to play in game arcade." K24

"It's more fun when you play with friends in game arcade." K28

Secondly, children preferred that they prefer game arcades because game arcades provide a suitable environment for them to play with their friends. The opinion of a participant is as follows:

"I can go to game arcade with my friends." K30

"There's no other place we can play with friends. I go to game arcade to play with them." K5

In addition, some of the children stated that they do not have enough physical conditions to play games at home and therefore they prefer game arcades. The views of some of the participants are as follows:

"I don't have a computer to play these games at home. It does not run most of the new games.

The computers in game arcades run all the games." K36 
In order to examine better the effect of environment on children's preferences on game arcades, children were asked "what are the differences between games that are played at game arcades and games played in other environments" (home, school, mobile, etc.). The findings are given in Table 5.

Table 5. Differences between games played in game arcades and other environments (home, school, mobile, etc.)

\begin{tabular}{lc}
\hline Differences & $f$ \\
\hline Game arcades are more fun, attractive and enjoyable & 13 \\
Circle of friends in game arcade & 12 \\
Absence of family pressure in game arcades & 7 \\
Time passes faster and better in game arcades & 6 \\
Inability to play in other environments due to financial difficulties & 5 \\
Better quality of devices in game arcades & 2 \\
\hline
\end{tabular}

When the table is examined, it is seen that children find game arcades more fun, attractive and enjoyable than other environments. In addition, since children can be together with their friends, they see game arcades differently than other environments. One participant opinion is:

"Playing games in game arcades is more fun than playing at home, we can be with friends." K48

Another noteworthy point is that the children stated that there was no parental supervision in game arcades. A participant's opinion on the subject is as follows:

"When my mother sees that I am constantly sitting at the computer, she gets angry and tells me to get up and study". K39

In addition, children stated that their time went faster in game arcades and that they could not play the games they wanted in other environments due to financial difficulties.

\section{The Effect of Peers on Children's Habits on Playing in Game Arcades}

Within the framework of the main purpose of the study, in order to evaluate the effect of peers on the gaming habits of children, it has been examined how long the children have used game arcades and with whose influence they started to use game arcades. The relevant data are presented in Table 6. 
Table 6. Peer effect on children's use of game arcades

\begin{tabular}{lclc}
\hline Duration of Usage & $f$ & Who influenced it & $f$ \\
\hline 1-3 years ago & 32 & Friend & 34 \\
3-5 years ago & 12 & Relative & 10 \\
6 years and above & 8 & Arcade owner & 5 \\
& & Instinctively & 3 \\
\hline
\end{tabular}

When Table 6 is examined, it is seen that children are more affected by their friends and relatives. Considering that their relatives, who introduced children to these environments, are largely from their own age groups, it can be said that a large number of children have met with game arcades through their peers. Although it is seen that children are acquainted with these environments through their peers (friends and relatives), the role of their peers in the habit of using these environments is also very important. The related findings are given in Table 7.

Table 7. The effect of friends on the visiting habits of game arcades

\begin{tabular}{lc}
\hline Whom do you go to game arcades with? & $f$ \\
\hline With my friends & 50 \\
With my relatives & 2 \\
& \\
Would you go to game arcades, even if you do not have friends? & 16 \\
\hline I would & 18 \\
I would go less frequently & 18 \\
\hline
\end{tabular}

When the table is examined, it is seen that most of the children prefer to go to game arcades with their friends. It is noteworthy that more than half of the children who participated in the study went to game arcades less often without their friends or never went to game arcades. Some participants' views on this subject are as follows:

"I don't think I would go to game arcade without my friends." K18

"It is nice to spend time in game arcade with friends. We usually go together. I've never been there alone." K21

At this point, in order to determine whether the habits of children going to game arcades with their friends had an effect on their game preferences, the participants were asked whether they played single-player games. The findings are given in Table 8. 
Table 8. Children's preferences of single-player games

\begin{tabular}{ll}
\hline Do you play single player games? & $f$ \\
\hline I do not & 33 \\
I do sometimes, but it's more fun to play with friends. & 16 \\
I do, single player games are more beautiful & 3 \\
\hline
\end{tabular}

When the table is examined, it is seen that more than half of the children who participated in the study did not play single-player games, and one of every three children played single-player games, but they found the games they played with their friends more enjoyable. A participant opinion on the subject is as follows:

"I am more amused to know that the person I play with is not a machine but a real person." K47

"Single player games are boring after a while, I don't play them much." K19

In addition, more than half of the children stated that they were very interested in their friends' suggestions when choosing the games, and that they preferred the games that were popular and liked among their friends.

\section{Discussion and Conclusions}

Firstly, the effect of game on children's gaming habits were examined. In this context, the factors that affect the digital game preferences of children were discussed. Predictably, children saw digital games more as a means of entertainment and spending time. In fact, the games were adopted as a means of entertainment even before the games underwent their digital evolution (De Grove, Bourgonjon \& Van Looy, 2012). This situation can be considered as a reflection of the natural structure of the games. Although the rules, the way they are played, or the environment they are played in change, the games always have and will continue to be an element of entertainment. The point that needs attention is the findings that say children prefer digital games to be with their friends. These findings contradict the generally justified criticism that digital games are turning children into asocial by detaching them from social life. It is at this point that the change and development of digital games should be looked at. With the development of the digital gaming industry, children's gaming preferences and reasons for choosing these games are also changing (Salmon, et al., 2017; Tuncay, 2016). Of course, it is difficult to say that single-player games' contribution to the socialization of children. However, multi-player games, which have become increasingly popular in recent years, seem to be the candidates for reversing this situation. This 
transformation of the digital games shows the effect on children's preference on game arcades (Rezaei \& Ghodsi, 2014). For example, the growing popularity of mobile games has significantly changed the tools used for digital games (Pala \& Erdem, 2011). In the context of the environment, most of the participants stated that they prefer multi-player digital games in game arcades. This situation, which is supported by the researches in the literature (Binark \& Bakratutan-Sütcü, 2008), can be said to affect both children's game preferences and habits of using game arcades. Starting from this effect of digital games on children's usage habits in game arcades, the reflections of the development of digital games on children's social lives can also be examined. Considering that digital games play an important role in the daily life of children (Connolly, Boyle, MacArthur, Hainey \& Boyle, 2012), it can be thought that indepth analysis of this issue will have valuable results.

In this research, the effect of environment as another factor affecting children's habits on using game arcades was examined. Children first considered game arcades as places where they could have fun with their friends. The physical conditions and technical infrastructure of game arcades are secondly stated. This situation contradicts with other researches in the literature. In fact, in the studies conducted by Gürol and Sevindik (2007) and Can and Kara (2010), physical conditions were the first factor affecting the children's usage of game arcades. However, as mentioned earlier, especially the development of digital games and the widespread use of multi-player games seem to have influenced the reasons why children prefer game arcades. In order to give depth to this point, the children who participated in the study were also asked about the differences between game arcades and other environments. As expected, physical conditions were also among these differences. However, what is remarkable is that physical conditions take the last place among the differences stated by children. Prior to this, the differences such as the game arcades are more entertaining, the circle of friendship and the lack of parental control were expressed by the children. One of the factors affecting children's playing habits in Internet cafes and game arcades is undoubtedly their families. Although the children have the opportunity to play the same games at home, the reasons for choosing game arcades include the fact that children want to play without the supervision of their parents. However, during the interviews, it was seen that the children would prefer to go to these environments even if their families did not interfere with their game. In addition, most of the children stated that they came to these environments and played games within the knowledge of their families. 
Given the increasing risks associated with internet and gaming addiction, parents' attitude towards game arcades can be seen as unexpected. However, similar findings can be seen in the literature (Hopcan \& Yilmaz, 2013). The findings of the research that is conducted by Liau, Khoo, and Ang (2008) with 1002 parents, are of a nature to help explain this situation. Liau, Khoo, and Ang (2008) found that parents have no objection for their children to use these environments, that parents were not fully aware of internet risks and game addiction, and that their children would not try risky behaviors in crowded environments such as game arcades. On the other hand, the research conducted by Binark and Bakratutan-Sütcü (2008) revealed that game arcades are seen as centers where crime and illegal works are performed. It may be thought that the conflicting findings on this subject are due to the fact that the participants have different levels of awareness on the subject or the diversity of the cultural approaches of the society in which the research is conducted. Therefore, new researches with large working groups that take cultural elements into consideration can make significant contributions to the literature.

In the study, peers were also examined as one of the factors affecting the habits of children to use game arcades. The findings showed that peers were an important factor in the habits of children to use game arcades. Almost all of the children participating in the study stated that they started to use game arcades through their peers. In order to take a deeper look at the impact of their peers on the habits on using game arcades, children's opinions about whom they went to game arcades with and whether they went to game arcades without their peers (friends / relatives) were also taken. The findings support other findings of this research. All of the children who participated in the study stated that they went to game arcades with their peers, and more than half of them did not go to game arcades alone or went less. These findings reveal how important their peers are in the use of game arcades. In fact, it is known that peer environment has a significant effect on the popularization of an internet application or digital game among children (Lauricella, 2013). In the literature, there are also findings that children tend to come to game arcades with their friends (Taşpınar \& Gümüş, 2005). Contrary to these research findings, Tsitsika et al. (2009) found in their study with 897 participants that the main impulse that pushed the participants to use game arcades was just to play games. The differences in the results of the research are quite natural considering the dates of the surveys. Because in the 10-15 years, both digital games and children's habits towards these games have changed significantly. 
Since digital gaming competitions are held around the world and these have a gradually increasing audience, it is possible to say that in the coming years, game arcades will be more popular environment than losing their popularity. In this context, it should be noted that multi-player online games have an undeniable impact on the gaming world, as well as indirectly affecting social environments such as game arcades in daily life, friendship relations in these environments, game addiction and many other areas that need to be scientifically researched. The research that would be carried out in this direction could provide in-depth information for better analysis of many problematic situations, from psychological problems to communication problems of children.

\section{References}

Akbulut, Y. (2013). Çocuk ve ergenlerde bilgisayar ve internet kullanımının gelişimsel sonuçları [Developmental Implications of Computer and Internet Use among Children and Adolescents]. Trakya Journal of Education, 3(2), 53-68.

Anderson, C. A., Gentile, D. A., \& Buckley, K. E. (2007). Violent video game effects on children and adolescents: Theory, research, and public policy. New York, United States: Oxford University Press.

Batı, U. (2011). Sekizinci sanatın inşası: “Dijital oyunlar kesişiminde postmodenizm, tüketim kültürü, üst gerçeklik, kimlik ve olağan şiddet" [Construction of the eighth art: "In the intersection of digital games, postmodernism, consumer culture, super-reality, identity and ordinary violence"]. In G. Terek Ünal ve U. Batı (Ed.), Dijital Oyunlar: Kendi Dünyanda Yaşa, Bizimkinde Oyna [Digital Games: Live in your own world, play in ours] (pp. 3-33). İstanbul: Derin Publications.

Binark, M., \& Bayraktutan-Sütcü, G. (2008). Türkiye'de internet kafeler: İnternet kafeler üzerine üretilen söylemler ve mekân-kullanıcı ilişkisi [Internet cafes in Turkey: User space relationships and discourse]. Amme İdaresi Dergisi, 41(1), 113-148.

Can, Y., \& Kara, B. (2010). İnternet kafeye devam etme alışkanlığı bulunan bireylerin bir alt kültür grubu olarak incelenmesi: Niğde örneği [Investigation of individuals with habit of attending internet cafes as a subculture group: The case of Niğde]. Journal of Sociological Research, 13(1), 37-66.

Connolly, T. M., Boyle, E. A., MacArthur, E., Hainey, T., \& Boyle, J. M. (2012). A systematic literature review of empirical evidence on computer games and serious games. Computers \& Education, 59(2), 661-686.

Çağlayan, S. (2001). Enformasyon toplumu: Internet kafeler ve kahvehanelerin karşılaştırmalı araştırması [The Information society: Comparative analyses internet cafes and kahvehanes]. (Master's thesis, Ege University, İzmir, Turkey).

Çavuş, S., Ayhan, B., \& Tuncer, M. (2016). Bilgisayar oyunları ve bağımlılık: Üniversite öğrencileri üzerine bir alan araştırması [Computer Games and Addiction: A Field Study on University Students]. Iletişim Kuram ve Araştırma Dergisi [Journal of Communication Theory and Research], 2016(43), 265-289. 
De Grove, F., Bourgonjon, J., \& Van Looy, J. (2012). Digital games in the classroom? A contextual approach to teachers' adoption intention of digital games in formal education. Computers in Human Behavior, 28(6), 2023-2033.

Glesne, C. (2012). Nitel araştırmaya giriş [Introduction to qualitative research]. (Translated A. Ersoy and P. Yalçınoğlu). Ankara: Anı Publishing.

Gürol, M., \& Sevindik, T. (2007). Profile of internet cafe users in Turkey. Telematics and Informatics, 24(1), 59-68.

Hopcan, S., \& Yılmaz, M. B. (2013). İlköğretim öğrencilerinin internet kafe kullanımlarının farklı değişkenlere göre incelenmesi [Analysis of Elementary School Students' Internet Cafe Usage in Respect to Different Variables]. HAYEF Journal of Education, 10(2), 23-34.

Kim, Y., \& Smith, D. (2017). Pedagogical and technological augmentation of mobile learning for young children interactive learning environments. Interactive Learning Environments, 25(1), 4-16.

Ko, C. H., Yen, J. Y., Chen, C. C., Chen, S. H., \& Yen, C. F. (2005). Gender differences and related factors affecting online gaming addiction among Taiwanese adolescents. The Journal of Nervous and Mental Disease, 193(4), 273-277.

Kuss, D. J., \& Griffiths, M. D. (2012). Online gaming addiction in children and adolescents: A review of empirical research. Journal of Behavioral Addictions 1(1), 3-22.

Lauricella, A. R. (2013). Çocukların Medya Katılımı [Media Participation of Children] (Translated A. Aksakal). 1. Türkiye Çocuk ve Medya Kongresi [Turkey Children and Media Congress] : 14-15 November Proceedings Book 2 (pp.117- 137). İstanbul: Çocuk Vakf1 Publications.

Liau, A. K., Khoo A., \& Ang, P.H. (2008). Parental awareness and monitoring of adolescent internet use. Current Psychology, 27(4), 217-233.

Lin, Y. H., \& Hou, H. T. (2016). Exploring young children's performance on and acceptance of an educational scenario-based digital game for teaching route-planning strategies: a case study. Interactive Learning Environments, 24(8), 1967-1980.

Olafsson, K., Livingstone, S., \& Haddon, L. (2013). Children's use of online technologies in Europe. A review of the European evidence base. LSE, London: EU Kids Online.

Pala, F. K., \& Erdem, M. (2011). Dijital oyun tercihi ve oyun tercih nedeni ile cinsiyet, sınıf düzeyi ve öğrenme stili arasındaki ilişkiler üzerine bir çalışma [A Study on the Relationships between Digital Game Preference and Game Preference Reason with Gender, Class Level and Learning Styles]. Journal of Kirsehir Education Faculty, 12(2), 53-71.

Rehbein, F., Psych, G., Kleimann, M., Mediasci, G., \& Mößle, T. (2010). Prevalence and risk factors of video game dependency in adolescence: results of a German nationwide survey. Cyberpsychology, Behavior, and Social Networking, 13(3), 269-277.

Reinhardt, A. (2001). The McDonald's of Net Access? Retrieved from http://www.businessweek.com/stories/2001-07-08/the-mcdonalds-of-net-access-intledition.

Rezaei, S., \& Ghodsi, S. S. (2014). Does value matters in playing online game? An empirical study among massively multiplayer online role-playing games (MMORPGs). Computers in Human Behavior, 35, 252-266.

Saleem, M., Anderson, C. A., \& Gentile, D. A. (2012). Effects of prosocial, neutral, and violent video games on children's helpful and hurtful behaviors. Aggressive Behavior, 38(4), 281287. 
Salmon, J. P., Dolan, S. M., Drake, R. S., Wilson, G. C., Klein, R. M., \& Eskes, G. A. (2017). A survey of video game preferences in adults: Building better games for older adults. Entertainment Computing, 21, 45-64.

Sherry, J., Desouza, R., Greenberg, B. S., \& Lachlan, K. (2003). Relationship between developmental stages and video game uses and gratifications, game preference and amount of time spent in play. Paper presented at the annual meeting of the International Communication Association, Marriott Hotel, San Diego, CA Online. Retrieved from http://citation.allacademic.com/meta/p_mla_apa_research_citation/1/1/1/9/3/p111930_i ndex.html.

Siyez, D. M., \& Baran, B. (2017). Determining reactive and proactive aggression and empathy levels of middle school students regarding their video game preferences. Computers in Human Behavior, 72(July 2017), 286-295.

Tarcan, A. (2005). Dünden bugüne internet üzerine felsefi yaklaşımlar [Philosophical approaches on internet from past to present]. Ahmet Tarcan (Ed.), In Internet and Society (pp.2-10). Ankara: Anı Publishing.

Taşpınar, M., \& Gümüş, Ç. (2005). Ülkemizde internet kafelerin ortam ve kullanıcı profili: Bilgi toplumu açısından değerlendirme [Media and user profile of internet cafes in our country: Evaluation in terms of information society]. Electronic Journal of Social Sciences, 4(14), 80-93.

Thorne, H. T., Smith, J. J., Morgan, P. J., Babic, M. J., \& Lubans, D. R. (2014). Video game genre preference, physical activity and screen-time in adolescent boys from lowincome communities. Journal of Adolescence, 37(8), 1345-1352.

Toran, M., Ulusoy, Z., Aydın, B., Deveci, T., \& Akbulut, A. (2016). Çocuklarin dijital oyun kullanimina ilişkin annelerin görüşlerinin değerlendirilmesi [Evaluation Of Mothers' Views Regarding Children's Use Of Digital Game]. Kastamonu Education Journal, 24(5), 2263-2278.

Tsitsika, A., Critselis, E., Kormas, G., Filippopoulou, A., Tounissidou, D. Freskou, A., Spiliopoulou, T., Louizou, A. Konstantoulaki, E., \& Kafetzis, D. (2009). Internet use and misuse: A multivariate regression analysis of the predictive factors of internet use among Greek adolescents. European Journal of Pediatrics, 168(6), 655-665.

Tuncay, N. (2016). Game preferences of 3 generations from the eye of students'. Journal of Computer and Education Research, 4(8), 154-178.

Wu, C-S., \& Cheng, F-F. (2007). Internet café addiction of Taiwanese adolescents. Cyberpsychology \& Behavior, 10(2), 220-225.

Yıldırım, A., \& Şimşek, H. (2013). Sosyal bilimlerde nitel araştırma yöntemleri [Qualitative research methods in the social sciences] (8th ed.). Ankara: Seçkin Publisher.

Yıldız, M. (2002). Bir kamu politikası aracı olarak internet kafeler [Internet cafes as a public policy tool]. Amme İdaresi Dergisi, 35(2), 77-92. 